\title{
The leafy vegetable amaranth (Amaranthus gangeticus) is a potent inhibitor of calcium availability and retention in rice-based diets
}

\author{
Torben Larsen ${ }^{1 *}$, Shakuntala H. Thilsted ${ }^{2}$, Sunil K. Biswas ${ }^{3}$ and Inge Tetens ${ }^{2}$ \\ ${ }^{1}$ Department of Animal Health and Welfare, Danish Institute of Agricultural Sciences, Research Centre Foulum, \\ PO Box 50, 8830 Tjele, Denmark \\ ${ }^{2}$ Department of Human Nutrition, The Royal Veterinary and Agricultural University, Rolighedsvej 30 , \\ 1958 Frederiksberg C, Denmark \\ ${ }^{3}$ Grain Quality and Nutrition Division, Bangladesh Rice Research Institute, Gazipur 1701, Bangladesh
}

(Received 17 September 2002 - Revised 28 March 2003 - Accepted 29 April 2003)

\begin{abstract}
Improvement in the nutritional quality of Bangladeshi rice-based diets is sought through increasing the amounts of vegetables, fish and legumes consumed. The aim of the present study was to compare the effects of rice-based diets on selected parameters of Ca and $\mathrm{P}$ availability and retention in young, growing rats. The study was designed as a randomised balance trial with five diets, eight animals per diet, and two balance periods of 1 week each. Apart from diet 1, which was a pure rice diet, the other four diets were composite diets and included the leafy vegetable, amaranth leaves (Amaranthus gangeticus), the small fish, mola (Amblypharyngodon mola), and lentils (Lens culinaris) in different amounts to simulate the average rural rice-based diet, the recommended diet, the recommended diet diluted with starch, and the recommended diet excluding amaranth leaves. The inclusion of amaranth leaves, mola and lentils significantly improved $\mathrm{N}$ and growth retention in the rats compared with the pure rice diet. However, a minor addition of amaranth $(0 \cdot 66 \mathrm{~g} / 100 \mathrm{~g}$ $\mathrm{DM}$ ) significantly reduced the fractional $\mathrm{Ca}$ absorption and retention. Femur bone mass and $\mathrm{Ca}$ and $\mathrm{P}$ densities were significantly lower in the rats fed the diets that included amaranth leaves. The observed inhibitory effect of the amaranth leaves on Ca absorption and utilisation was probably due to the oxalate content. It is concluded that the formulation of a recommended diet cannot be based only on nutrient content values of individual food components due to interactions between nutrients and anti-nutrients in the diet.
\end{abstract}

Food and nutrition security: Micronutrient deficiency: Anti-nutrients: Mineral bioavailability: Small fish

Human diets should provide sufficient nutrients for maintenance, growth and body functions. In many lowincome countries, however, the diet is dominated by a single staple food and has only minor amounts of other food items, resulting in a monotonous diet and a high risk of insufficient intakes of both macro- and micronutrients.

As in many other Asian countries, the diet in Bangladesh is rice-based. Parboiled polished rice is the staple food and other foods such as vegetables, fish, pulses, fruits and animal products only constitute a minor part of the diet. National dietary surveys in rural Bangladesh (Ahmad \& Hassan, 1983; Ahmed, 1993; Jahan \& Hossain, 1998) and minor dietary studies (Hels et al. 2003) reveal that the average rice-based rural diet does not meet the daily recommendations, neither with regard to quantity (energy) nor quality (micronutrients). Dietary surveys show that rice provides up to $80 \%$ of the mean energy intake (Tetens et al. 2003) and that the intakes of nutrients not found in rice, or found in low levels, are insufficient to meet the recommendations. This situation of food and nutrition insecurity is the main explanation for the poor overall nutritional status in the Bangladeshi population as seen by the very high prevalences of stunting among children and chronic energy deficiency among rural adults, 60 and $48 \%$ respectively (Jahan \& Hossain, 1998). In addition, deficiencies of minerals and vitamins are a major public health problem (Ministry of Health and Family Welfare, 1995; Ahmed, 1999).

The Ministry of Health and Family Welfare, Bangladesh in collaboration with the Bangladesh Nutrition Council has proposed a recommended diet that should provide all the nutrients needed for a balanced diet (Ministry of Health and Family Welfare, 1995). The recommended diet is based on the commonly consumed foods: rice, leafy vegetables, fish and pulses but with larger amounts of leafy vegetables, fish and pulses than those found in the average rural diet.

\footnotetext{
Abbreviation: OM, organic matter.

* Corresponding author: Dr Torben Larsen, fax +45 899915 00, email Torben.Larsen@agrsci.dk
} 
Both fish and pulses will increase the protein and micronutrient contents of the rice-based diet. Fish has a high content of protein with a high biological value and lentils also have a relatively high protein content. This protein is especially rich in lysine, which compensates for the low lysine content in rice, thereby enhancing the biological value of the protein in the composite diet (Eggum, 1973). In addition to protein, fish and lentils are rich in minerals and trace elements.

Vegetables, especially leafy vegetables, are important in the diet as they are micronutrient-dense foods, rich in $\beta$-carotene, folic acid and minerals such as $\mathrm{Ca}, \mathrm{Fe}$ and $\mathrm{P}$ (Ali \& Tsou, 1997; Lakshmi \& Vimala, 2000). While recommendations of an increased intake of leafy vegetables are usually based on their contributions of $\beta$-carotene and vitamin C (Ali \& Tsou, 1997), little attention has been paid to the possible interactions between nutrients and in particular the possible negative nutritional effects due to the content of anti-nutrients, such as oxalates and phytic acid.

The aim of the present study was to compare the availability and retention of $\mathrm{Ca}$ and $\mathrm{P}$ from different rice-based diets. The diets studied included compositions similar to the average rural Bangladeshi diet as found in dietary studies and the recommended diet, as recommended by the Ministry of Health and Family Welfare, Bangladesh (Ministry of Health and Family Welfare, 1995). This was done by studying the effects on selected parameters related to the deposition of $\mathrm{Ca}$ and $\mathrm{P}$ in young, growing Wistar rats.

\section{Materials and methods}

\section{Dietary components}

The food components in the diets comprised rice, a leafy vegetable, a small fish and lentils. The rice (Oryza sativa L.) used was a high-yielding variety (BR11) grown at the Bangladesh Rice Research Institute, Gazipur, Bangladesh. After harvest, the rice was parboiled, sun-dried and milled using standard procedures. The rice was cooked in surplus water for the minimum cooking time (Tetens et al. 1997) and sun-dried. The leafy vegetable, amaranth leaves (Amaranthus gangeticus), locally called lalshak, was bought from the local market in Gazipur, Bangladesh. After separation of the non-edible parts, the amaranth leaves were cooked according to a traditional method and sun-dried. The small fish, mola (Amblypharyngodon mola), was bought from the local market, cleaned with ash and the viscera removed. The fish was washed and cooked according to a traditional method before being sun-dried. Lentils (Lens culinaris) were grown at the Bangladesh Agricultural Research Institute, Gazipur, Bangladesh. After harvest, the lentils were boiled in water and sun-dried.

All food components were homogenised using a wooden mortar and a pestle. The contents of ash and selected nutrients in the food components used in the diets are shown in Table 1.

\section{Experimental diets}

The experimental diets were composed of the food components mentioned earlier, $\mathrm{N}$-free maize starch, rapeseed oil $(4.0 \mathrm{~g} / 100 \mathrm{~g}$ diet $)$, a vitamin mixture $(1.6 \mathrm{~g} / 100 \mathrm{~g}$ diet $)$ and $\mathrm{NaCl}(0.5 \mathrm{~g} / 100 \mathrm{~g}$ diet $)$ to fulfil the recommendations for young, growing rats (Eggum, 1973). Five different diets were prepared (Table 2): diet 1, the rice diet; diet 2 , the average diet in rural Bangladesh; diet 3, the recommended diet modified to provide the same $\mathrm{N}$ level as diet 2; diet 4 , the recommended diet composed to fulfil the recommendations for the Bangladeshi rural population; diet 5, the recommended diet - amaranth leaves (amaranth was substituted by rice). To diet $1,800 \mathrm{mg} \mathrm{Ca}$ as $\mathrm{Ca}$ carbonate (analytical grade) per $\mathrm{kg}$ diet was added.

The contents of ash, N, Ca and P of the experimental diets are shown in Table 3.

\section{Animals, feeding and experimental design}

Male Wistar rats, 4 weeks old, with a weight of approximately $74 \mathrm{~g}$ at the start of the experiment were used. A total of forty rats were randomised in the five experimental diets within eight blocks. The rats were housed individually in plexiglass metabolic cages with a mesh bottom of stainless steel. The environment was controlled with regard to humidity ( $60 \%$ relative humidity), temperature $\left(25^{\circ} \mathrm{C}\right)$ and light $(12 \mathrm{~h}$ light and dark cycles). Redistilled drinking water was supplied ad libitum throughout the experiment. Feed was supplied ad libitum throughout the experiment and the consumption recorded daily. Faeces and urine were collected quantitatively daily during the two balance periods, i.e. days $7-14$ and days $21-28$, as described by Larsen et al. (2000). The faeces were lyophilised and ground into a fine powder using a mortar and a pestle of porcelain. The urine was preserved with dilute hydrochloric acid during collection. The rats were weighed on days $0,7,14,21$ and 28 .

Table 1. The content of ash and selected nutrients in the food components ( $\mathrm{g} / \mathrm{kg}$ dry matter) (Mean values of three analyses and corresponding coefficients of variation)

\begin{tabular}{|c|c|c|c|c|c|c|c|c|}
\hline & \multicolumn{2}{|c|}{ Rice } & \multicolumn{2}{|c|}{ Amaranth leaves } & \multicolumn{2}{|c|}{ Mola fish } & \multicolumn{2}{|c|}{ Lentils } \\
\hline & Mean & CV (\%) & Mean & CV (\%) & Mean & CV (\%) & Mean & $\mathrm{CV}(\%)$ \\
\hline Ash & $7 \cdot 1$ & 1.4 & 237.9 & 0.7 & 138.1 & 0.2 & 24.0 & 0.5 \\
\hline $\mathrm{N}$ & $15 \cdot 0$ & 2.9 & 41.8 & $2 \cdot 3$ & 105.8 & $2 \cdot 3$ & $46 \cdot 2$ & 2.4 \\
\hline $\mathrm{Ca}$ & 0.23 & 2.0 & $28 \cdot 7$ & $2 \cdot 0$ & $39 \cdot 12$ & 1.0 & 0.41 & $2 \cdot 3$ \\
\hline $\mathrm{P}$ & 1.27 & 0.5 & $6 \cdot 23$ & $2 \cdot 6$ & 24.61 & 1.7 & 3.47 & 0.3 \\
\hline
\end{tabular}


Table 2. Composition of the experimental diets ( $\mathrm{g} / 100 \mathrm{~g}$ dry matter)

\begin{tabular}{lccccc}
\hline Diet $^{\star} \ldots$ & Diet 1 & Diet 2 & Diet 3 & Diet 4 & Diet 5 \\
\hline Rice & 94.40 & 90.64 & 55.66 & 75.90 & 81.94 \\
Amaranth leaves & - & 0.66 & 4.43 & 6.04 & - \\
Mola fish & - & 1.50 & 4.07 & 5.57 & 5.57 \\
Lentils & - & 1.61 & 5.05 & 6.89 & 6.89 \\
N-free starch & - & - & 25.2 & - & - \\
Oil and vitamin mix & 5.60 & 5.60 & 5.60 & 5.60 & 5.60 \\
NaCl & 0.50 & 0.50 & 0.50 & 0.50 & 0.50 \\
\hline
\end{tabular}

* Diet 1 was the rice diet. Diet 2 was the average diet in rural Bangladesh (Ahmad \& Hassan, 1983). Diet 3 was the recommended diet, modified to provide the same protein level as diet 2 , by addition of $\mathrm{N}$-free starch. Diet 4 was the recommended diet for the rural Bangladesh population (Ministry of Health and Family Welfare, 1995). Diet 5 was the recommended diet (diet 4) minus amaranth leaves, which were replaced by rice.

†The oil and vitamin mix consisted of $4.0 \mathrm{~g}$ rapeseed oil and $1.6 \mathrm{~g}$ vitamin mixture per $100 \mathrm{~g}$ diet (Eggum, 1973). The vitamin mixture comprised $(\mathrm{mg} / \mathrm{kg}$ diet DM): retinyl acetate 1.4; cholecalciferol 2.1; DL- $\alpha$-tocopheryl succinate 64 ; menadione sodium bisulfite 6.6 ; pteroylmonoglutamic acid 1.1 ; thiamin hydrochloride 4.0 ; pyridoxine chloride 6.4 ; riboflavin 3.2 ; nicotinamide 20; calcium pantothenate 8.0 ; biotin 0.4 ; cyanocobalamin 0.048; choline chloride 1120 (analytical grade).

On day 28, the rats were anaesthetised in an atmosphere of $\mathrm{CO}_{2}$ and killed by puncturing the heart with a stainlesssteel needle. Blood was drawn from the heart, transferred to a heparinised tube, placed on ice and plasma was separated and stored frozen. The femur bones were dissected, loose tissue and cartilage were removed, and the bones were rinsed in a saline solution and frozen before freezedrying.

The cages as well as the utensils in direct contact with the animals, feed and excreta were washed in dilute $(2 \mathrm{M})$ nitric acid and thoroughly rinsed with distilled water before use.

\section{Analytical methods}

$\mathrm{DM}$ and ash contents in the feeds, faeces and bones were determined using standard methods. $\mathrm{N}$ in the diets, faeces and urine was determined by the Kjeldahl method (Kjel Tec 1030; Tecator, Höganäs, Sweden) after a sample digestion. $\mathrm{P}$ in the diets, faeces, urine and bones was quantified using the colorimetric vanado-molybdate method (Stuffins, 1967) after sample mineralisation. Ca was analysed by atomic absorption spectrophotometry (Pye Unicam PU 9400 X; Philips Scientific, Cambridge, UK), as described by Larsen \& Sandström $(1993 a)$. The activity of alkaline phosphatase in plasma was determined according to Bowers \& McComb (1975). Total Ca and inorganic
$\mathrm{P}$ in plasma were determined using an autoanalyser system (OpeRA $^{\mathrm{TM}}$; Bayer Corp., Tarrytown, NY, USA) and standardised methods. The chemical analyses of feeds and food components were done in triplicate while all other analyses were carried out in duplicate.

\section{Presentation of results and statistical methods}

Analyses of feeds and excreta from each balance period were performed separately and the results subsequently pooled, so that for each animal, only one value for each parameter was obtained. The ad libitum feeding resulted in different growth rates of the animals and thus the assessment of absolute element turnover was not relevant. The results are therefore presented in relation to $\mathrm{N}$ retention, used as an indicator of the lean body growth increment of the animal (Larsen et al. 2000). Overall, in the presentation of the results, the terms digestibility and absorption are used for apparent digestibility and apparent absorption, respectively.

The experiment was designed as a complete and balanced trial with five treatments carried out in eight blocks. The data were subjected to statistical ANOVA, using the model: $X_{i j}=\mu+\alpha_{i}+\beta_{j}+\varepsilon_{i j}$, with $X_{i j}$ as the dependent variable, $\mu$, the grand mean, $\alpha_{i}$, the effect of diet, $\beta_{\mathrm{j}}$, the effect of the block arrangement, and $\varepsilon_{\mathrm{ij}}$, the normal distributed random variation.

All statistical calculations were performed using the Statistical Analysis Systems software package, version 6.11 (SAS Institute Inc., 1996).

\section{Results}

\section{Nutrient composition of the diets}

There were large differences in the values obtained for ash, $\mathrm{N}, \mathrm{Ca}$ and $\mathrm{P}$ in the food components. On a dry-weight basis, the rice was relatively low in protein and ash (including $\mathrm{Ca}$ and $\mathrm{P}$ ), the lentils were rich in protein, and the amaranth leaves had a similar protein content to the lentils but a much higher content of ash, in particular Ca (Table 1). Compared with the other food components, the mola fish had the highest content of protein and $\mathrm{Ca}$ (Table 1).

The nutrient content of the individual food components was mirrored in the nutrient composition of the diets (Tables 2 and 3). Compared with the other diets, diet 4 had the highest content, in terms of $\mathrm{g} / \mathrm{kg} \mathrm{DM}$, of $\mathrm{N}$ (23.4), ash (29.8) and Ca (4.04). As planned, diet 3 had a similar protein content to diet 2 (Table 3 ). The replacement

Table 3. Ash, nitrogen, calcium and phosphorus content of the five experimental diets ( $\mathrm{g} / \mathrm{kg}$ dry matter)*

(Mean values of three determinations and corresponding coefficients of variation)

\begin{tabular}{|c|c|c|c|c|c|c|c|c|c|c|}
\hline \multirow{2}{*}{ Diet... } & \multicolumn{2}{|c|}{ Diet 1} & \multicolumn{2}{|c|}{ Diet 2} & \multicolumn{2}{|c|}{ Diet 3} & \multicolumn{2}{|c|}{ Diet 4} & \multicolumn{2}{|c|}{ Diet 5} \\
\hline & Mean & CV (\%) & Mean & CV (\%) & Mean & CV (\%) & Mean & CV (\%) & Mean & CV (\%) \\
\hline Ash & 8.7 & $1 \cdot 1$ & $11 \cdot 0$ & $2 \cdot 4$ & 21.0 & 0.7 & 29.8 & 0.9 & $15 \cdot 6$ & 0.6 \\
\hline $\mathrm{N}$ & 14.6 & $2 \cdot 8$ & $16 \cdot 3$ & $2 \cdot 3$ & $17 \cdot 4$ & 2.5 & 23.4 & 3.0 & 21.8 & 1.9 \\
\hline $\mathrm{Ca}$ & 0.95 & 1.9 & 0.96 & $4 \cdot 1$ & 2.88 & 0.4 & 4.04 & $2 \cdot 7$ & $2 \cdot 40$ & 1.7 \\
\hline $\mathrm{P}$ & 1.19 & 3.2 & 1.61 & 1.8 & 2.09 & 0.9 & 2.92 & 0.9 & 2.61 & $2 \cdot 1$ \\
\hline
\end{tabular}

${ }^{*}$ For details of the diets, see Table 2. 
of amaranth leaves with rice, in diet 5 , resulted in diet 5 having a relatively high protein content $(21.8 \mathrm{~g} \mathrm{~N} / \mathrm{kg} \mathrm{DM})$ and an ash content of only half that of diet 4 (Table 3 ).

\section{Body weight, intake, digestibility and retention of dry} matter, organic matter and protein

The mean initial body weight of the animals in each dietary group was similar, whereas the mean final body weight differed significantly between dietary groups (Table 4). The mean daily body weight gain in the rats was between $2.2 \mathrm{~g} / \mathrm{d}$ (diet 1) and $3.7 \mathrm{~g} / \mathrm{d}$ (diets 4 and 5).

The mean feed intake expressed as DM or organic matter (OM) intake was significantly lower in the rats fed diet 1 compared with those fed the other diets, whereas the total mean ash intake differed significantly between diets (Table 4). The fractional digestibility of feed DM and $\mathrm{OM}$ was above $92 \%$ for all diets (Table 4). Diet 1 had the highest digestibility, while the inclusion of other food components in diets 2-5 led to a significant reduction in the fractional digestibility of DM and OM. The intake of ash was closely related to the inclusion of the food items other than rice, resulting in significantly different intakes in the different dietary groups, with the highest intake in diet 4. The fractional absorption of ash ranged from 0.799 in diet 5 to 0.595 in diet 4 (Table 4).

The parameters related to the $\mathrm{N}$ intake, digestion and retention are shown in Table 5. The $\mathrm{N}$ intake differed significantly between dietary groups, with the highest intake in diet 4. For all diets, the fractional digestibility of $\mathrm{N}$ was close to $80 \%$, although there were significant differences between diets. The fractional retention of $\mathrm{N}$ as well as $\mathrm{N}$ in urine as a proportion of the absorbed amount reflected the quality of the protein ingested. The poor quality of the protein in diet 1 compared with that of the other composite diets is clearly indicated in Table 5. The quality of the protein in diet 4 was significantly lower than that in diet 5 . Body growth per $\mathrm{g} \mathrm{N}$ retention reflects the body composition. Table 5 shows that the rats on diets 1 and 2 had a higher growth per $\mathrm{g} \mathrm{N}$ retention compared with those on diets 4 and 5, indicating that the rats from the latter groups were leaner.

\section{Intake, fractional absorption and retention of calcium and phosphorus in relation to nitrogen retention}

The mean $\mathrm{Ca}$ intake differed significantly between diets (Table 6). The fractional $\mathrm{Ca}$ absorption ranged from 0.398 in diet 4 to 0.977 in diet 1 and was inversely related to intake. The exclusion of amaranth leaves from the recommended diet (diet 5) increased the fractional Ca absorption significantly to 0.933 . The body retention of $\mathrm{Ca}$ in relation to the lean body mass ( $\mathrm{N}$ retention) showed significant differences between diets; the highest $\mathrm{Ca}$ retention was found in diet 5 and the lowest in diet 2.

The mean $\mathrm{P}$ intake differed significantly between diets (Table 7). However, the fractional absorption of $\mathrm{P}$ in the diets differed less than that of $\mathrm{Ca}$, from 0.89 in diets 1,2

Table 4. Body weight, feed, organic matter $(\mathrm{OM})$ and ash intake and digestibility in young rats* (Pooled mean values)

\begin{tabular}{|c|c|c|c|c|c|c|c|}
\hline Diet... & Diet 1 & Diet 2 & Diet 3 & Diet 4 & Diet 5 & $\sqrt{ }$ MSE & $P<$ \\
\hline Initial body weight (g) & $74 \cdot 3^{a}$ & $73 \cdot 5^{a}$ & $74 \cdot 3^{a}$ & $74 \cdot 1^{a}$ & $74 \cdot 0^{\mathrm{a}}$ & 3.4 & NS \\
\hline Final body weight $(\mathrm{g})$ & $136 \cdot 1^{c}$ & $153 \cdot 8^{b}$ & $151 \cdot 3^{b}$ & $176 \cdot 4^{a}$ & $174 \cdot 4^{a}$ & $7 \cdot 0$ & 0.001 \\
\hline Feed intake (g DM/d) & $10 \cdot 95^{\mathrm{b}}$ & $11 \cdot 65^{a}$ & $11.92^{\mathrm{a}}$ & $12 \cdot 09^{a}$ & $11.95^{\mathrm{a}}$ & 0.49 & 0.001 \\
\hline Fractional DM digestibility & $0 \cdot 970^{\mathrm{a}}$ & $0.963^{b}$ & $0.941^{d}$ & $0.925^{\mathrm{e}}$ & $0.954^{c}$ & 0.006 & 0.001 \\
\hline OM intake (g DM/d) & $10 \cdot 85^{\mathrm{b}}$ & $11 \cdot 52^{\mathrm{a}}$ & $11 \cdot 67^{\mathrm{a}}$ & $11 \cdot 73^{a}$ & $11 \cdot 76^{\mathrm{a}}$ & 0.49 & 0.01 \\
\hline Fractional OM digestibility & $0.972^{a}$ & $0.965^{b}$ & $0.948^{d}$ & $0.935^{\mathrm{e}}$ & $0.956^{c}$ & 0.006 & 0.001 \\
\hline Ash intake $(\mathrm{g} / \mathrm{d})$ & $0.096^{e}$ & $0.129^{d}$ & $0 \cdot 249^{b}$ & $0.362^{a}$ & $0.185^{c}$ & 0.006 & 0.001 \\
\hline Fractional ash absorption & $0.767^{b}$ & $0.726^{c}$ & $0.608^{d}$ & $0.595^{d}$ & $0.799^{a}$ & 0.022 & 0.001 \\
\hline
\end{tabular}

JMSE, root mean square error of the statistical analysis (d.f. 28).

a,b,c,d,e Mean values within a row with unlike superscript letters were significantly different $(P<0.05)$.

${ }^{\star}$ For details of diets, see Table 2.

Table 5. Nitrogen intake, digestible nitrogen and nitrogen retention in young rats*

(Pooled mean values)

\begin{tabular}{|c|c|c|c|c|c|c|c|}
\hline $\mathrm{N}$ intake $(\mathrm{mg} / \mathrm{d})$ & $160 \cdot 3^{d}$ & $191 \cdot 6^{c}$ & $194 \cdot 4^{c}$ & $283 \cdot 8^{a}$ & $261 \cdot 6^{\mathrm{b}}$ & 7.93 & 0.001 \\
\hline Digestible N (mg/d) & $131 \cdot 5^{d}$ & $157 \cdot 2^{c}$ & $153 \cdot 2^{c}$ & $227 \cdot 9^{a}$ & $214 \cdot 8^{b}$ & $7 \cdot 37$ & 0.001 \\
\hline Fractional $\mathrm{N}$ digestibility & $0.820^{a}$ & $0.820^{a}$ & $0.787^{c}$ & $0 \cdot 802^{b}$ & $0.821^{a}$ & 0.012 & 0.001 \\
\hline $\mathrm{N}$ retention $(\mathrm{mg} / \mathrm{d})$ & $64 \cdot 0^{c}$ & $88 \cdot 9^{b}$ & $90 \cdot 3^{\mathrm{b}}$ & $128 \cdot 4^{\mathrm{a}}$ & $127 \cdot 0^{\mathrm{a}}$ & $5 \cdot 5$ & 0.001 \\
\hline Fractional $\mathrm{N}$ retention & $0.399^{c}$ & $0.469^{\mathrm{ab}}$ & $0.463^{\mathrm{b}}$ & $0.451^{b}$ & $0.485^{\mathrm{a}}$ & 0.018 & 0.001 \\
\hline
\end{tabular}

$\sqrt{ }$ MSE, root mean square error of the statistical analysis (d.f. 28).

$\mathrm{a}, \mathrm{b}, \mathrm{c}, \mathrm{d}$ Mean values within a row with unlike superscript letters were significantly different $(P<0.05)$

* For details of diets, see Table 2. 
Table 6. Calcium intake, absorption and retention in young rats*

(Pooled mean values)

\begin{tabular}{|c|c|c|c|c|c|c|c|}
\hline Diet... & Diet 1 & Diet 2 & Diet 3 & Diet 4 & Diet 5 & $\sqrt{ }$ MSE & $P<$ \\
\hline Ca intake $(\mathrm{mg} / \mathrm{d})$ & $10 \cdot 4^{e}$ & $11 \cdot 2^{d}$ & $34 \cdot 3^{\mathrm{b}}$ & $48 \cdot 8^{a}$ & $28 \cdot 7^{\mathrm{C}}$ & 0.79 & 0.001 \\
\hline Ca absorption (mg/d) & $10 \cdot 2^{d}$ & $9 \cdot 4^{\mathrm{d}}$ & $14 \cdot 6^{\mathrm{c}}$ & $19 \cdot 6^{\mathrm{b}}$ & $26 \cdot 8^{a}$ & 0.93 & 0.001 \\
\hline Fractional $\mathrm{Ca}$ absorption & $0.977^{a}$ & $0.838^{c}$ & $0.424^{d}$ & $0.398^{e}$ & $0.933^{b}$ & 0.023 & 0.001 \\
\hline Ca retention $(\mathrm{mg} / \mathrm{d})$ & $9 \cdot 9^{d}$ & $9 \cdot 1^{d}$ & $14 \cdot 4^{\mathrm{C}}$ & $19 \cdot 3^{b}$ & $26 \cdot 5^{a}$ & 0.91 & 0.001 \\
\hline Fractional $\mathrm{Ca}$ retention & $0.954^{a}$ & $0.817^{c}$ & $0.416^{d}$ & $0.392^{e}$ & $0.920^{\mathrm{b}}$ & 0.023 & 0.001 \\
\hline Ca urine:Ca absorption & $0.024^{a}$ & $0.022^{\mathrm{ab}}$ & $0.019^{\mathrm{bc}}$ & $0.016^{\mathrm{cd}}$ & $0.014^{d}$ & 0.004 & 0.001 \\
\hline Ca retention/N retention $(\mathrm{g} / \mathrm{g})$ & $0.155^{\mathrm{bc}}$ & $0 \cdot 102^{d}$ & $0.159^{b}$ & $0.151^{\mathrm{c}}$ & $0.209^{a}$ & 0.008 & 0.001 \\
\hline
\end{tabular}

JMSE, root mean square error of the statistical analysis (d.f. 28).

a,b,c,d Mean values within a row with unlike superscript letters were significantly different $(P<0.05)$.

${ }^{*}$ For details of diets, see Table 2.

and 5 to 0.85 in diets 3 and 4 . The urinary excretion of $\mathrm{P}$ differed markedly, resulting in significantly different fractional $\mathrm{P}$ retention between groups, ranging from 0.45 to 0.64 . The $\mathrm{P}$ retention in relation to $\mathrm{N}$ retention differed significantly between groups, with the lowest values in diets 2 and 4 and the highest value in diet 5 .

Femur bone mass, content of calcium and phosphorus, and calcium:phosphorus

Femur bone mass differed significantly between the dietary groups, with the highest mean value in diet 5 and the lowest mean value in diet 2 (Table 8 ). When bone mass was expressed per $\mathrm{g}$ body weight, similar significant differences were seen. Significantly higher contents of $\mathrm{Ca}$ and $\mathrm{P}$ per $\mathrm{kg}$ ash were seen in diet 5 compared with the other diets, reflecting that the mineralisation of the bone was significantly higher in the rats on diet 5. Ca:P of the femur bones was similar in all dietary groups.

Plasma levels of calcium, inorganic phosphorus and alkaline phosphatase

Plasma levels of $\mathrm{Ca}$ and inorganic $\mathrm{P}$ were similar for all dietary groups (Table 8). Plasma alkaline phosphatase was significantly lower in the rats on diets 3,4 and 5 compared with those on diets 1 and 2 (Table 8), emphasising the inverse correlation between bone growth and the concentration of alkaline phosphatase in the blood.

\section{Discussion}

The results of the present study showed that the availability and retention of $\mathrm{Ca}$ and $\mathrm{P}$ of a rice diet were significantly changed by the addition of other food components when evaluated in young, growing rats. Furthermore, the results underlined the importance of interactions between nutrients in a composite diet.

Apart from diet 1, which was composed only of rice, the four other diets were composite diets comprising amaranth leaves, small fish and lentils, commonly consumed food items in rural Bangladesh. Diet 2 was composed of the four food components of rice, amaranth leaves, mola fish and lentils, in amounts reported from dietary surveys in rural Bangladesh (Ahmad \& Hassan, 1983). This diet contained insufficient amounts of vitamins and minerals, such as vitamin A, folic acid, Fe, Ca and I (Ahmad \& Hassan, 1983; Ministry of Health and Family Welfare, 1995). The recommended diet (diet 4) comprised the same food items as the average diet (diet 2) but in amounts that fulfil the daily recommendations of most nutrients (Ministry of Health and Family Welfare, 1995).

The mean daily feed and OM intakes of the composite diets (diets 2-5) were similar and significantly higher than that of the rice diet (diet 1). However, inclusion of amaranth leaves, mola fish and lentils reduced the fractional digestibility of both DM and OM (Table 4). The mean intake of ash was determined predominantly by the amount of amaranth leaves included in the diets, due to the high content of minerals, in particular $\mathrm{Ca}$ in the amaranth leaves (approximately $3 \%$ DM). The difference

Table 7. Phosphorus intake, absorption and retention in young rats*

(Pooled mean values)

\begin{tabular}{|c|c|c|c|c|c|c|c|}
\hline Diet... & Diet 1 & Diet 2 & Diet 3 & Diet 4 & Diet 5 & $\sqrt{ } \mathrm{MSE}$ & $P<$ \\
\hline$P$ intake $(\mathrm{mg} / \mathrm{d})$ & $13 \cdot 1^{\mathrm{e}}$ & $18 \cdot 7^{d}$ & $24 \cdot 9^{c}$ & $35.4^{a}$ & $31 \cdot 2^{b}$ & 0.80 & 0.001 \\
\hline P absorption (mg/d) & $10 \cdot 9^{e}$ & $14.9^{d}$ & $18 \cdot 6^{\mathrm{c}}$ & $26 \cdot 1^{\mathrm{a}}$ & $24 \cdot 3^{b}$ & 0.84 & 0.001 \\
\hline Fractional $\mathrm{P}$ absorption & $0.888^{a}$ & $0.887^{\mathrm{a}}$ & $0.856^{b}$ & $0.848^{\mathrm{b}}$ & $0.889^{a}$ & 0.025 & 0.01 \\
\hline$P$ retention $(\mathrm{mg} / \mathrm{d})$ & $7.54^{\mathrm{e}}$ & $8 \cdot 97^{d}$ & $11.57^{\mathrm{C}}$ & $13 \cdot 93^{\mathrm{b}}$ & $17 \cdot 37^{\mathrm{a}}$ & $1 \cdot 24$ & 0.001 \\
\hline Fractional $\mathrm{P}$ retention & $0 \cdot 611^{a}$ & $0.534^{b}$ & $0.531^{b}$ & $0.453^{c}$ & $0.636^{\mathrm{a}}$ & 0.048 & 0.001 \\
\hline $\mathrm{P}$ urine: $\mathrm{P}$ absorption & $0.312^{\mathrm{c}}$ & $0.398^{b}$ & $0.380^{b}$ & $0.465^{a}$ & $0.285^{c}$ & 0.046 & 0.001 \\
\hline$P$ retention/ $N$ retention $(\mathrm{g} / \mathrm{g})$ & $0.118^{\mathrm{bc}}$ & $0 \cdot 101^{d}$ & $0.128^{a b}$ & $0 \cdot 108^{\mathrm{cd}}$ & $0.137^{a}$ & 0.011 & 0.001 \\
\hline
\end{tabular}

$\sqrt{ }$ MSE, root mean square error of the statistical analysis (d.f. 28).

$a, b, c$ Mean values within a row with unlike superscript letters were significantly different $(P<0.05)$

${ }^{*}$ For details of diets, see Table 2. 
Table 8. Femur bone mass, calcium and phosphorus content and selected plasma parameters in rats at the end of the experiment* (Pooled mean values)

\begin{tabular}{|c|c|c|c|c|c|c|c|}
\hline Diet... & Diet 1 & Diet 2 & Diet 3 & Diet 4 & Diet 5 & $\sqrt{ }$ MSE & $P<$ \\
\hline \multicolumn{8}{|l|}{ Femur bone } \\
\hline Bone DM (g) & $0.324^{\mathrm{cd}}$ & $0.318^{d}$ & $0.335^{c}$ & $0.380^{\mathrm{b}}$ & $0.425^{a}$ & 0.015 & 0.001 \\
\hline Bone ash (\% DM) & $46 \cdot 8^{\mathrm{b}}$ & $43 \cdot 8^{\mathrm{C}}$ & $46 \cdot 3^{b c}$ & $48 \cdot 8^{\mathrm{b}}$ & $51 \cdot 9^{\mathrm{a}}$ & $2 \cdot 51$ & 0.001 \\
\hline $\mathrm{Ca}(\mathrm{g} / \mathrm{kg}$ ash) & $167 \cdot 1^{b}$ & $154 \cdot 4^{c}$ & $166 \cdot 0^{\mathrm{b}}$ & $172 \cdot 2^{b}$ & $189 \cdot 1^{a}$ & $7 \cdot 2$ & 0.001 \\
\hline $\mathrm{P}(\mathrm{g} / \mathrm{kg}$ ash $)$ & $87 \cdot 3^{b}$ & $81 \cdot 4^{c}$ & $86 \cdot 9^{b}$ & $89 \cdot 6^{b}$ & $97 \cdot 0^{\mathrm{a}}$ & $3 \cdot \overline{8}$ & 0.001 \\
\hline $\mathrm{Ca}: \mathrm{P}$ & 1.91 & 1.90 & 1.91 & 1.92 & 1.95 & 0.039 & NS \\
\hline \multicolumn{8}{|l|}{ Plasma concentration } \\
\hline Total Ca $(\mathrm{mmol} / \mathrm{l})$ & $2 \cdot 84$ & $2 \cdot 88$ & $2 \cdot 70$ & $2 \cdot 76$ & $2 \cdot 76$ & $0 \cdot 15$ & 0.171 \\
\hline Inorganic $\mathrm{P}(\mathrm{mmol} / \mathrm{l})$ & 3.65 & 3.62 & 3.57 & 3.79 & 3.58 & 0.27 & 0.481 \\
\hline Alkaline phosphatase (U/I) & $515^{\mathrm{ab}}$ & $597^{\mathrm{a}}$ & $469^{a b c}$ & $391^{\mathrm{bc}}$ & $341^{\mathrm{c}}$ & 128 & 0.004 \\
\hline
\end{tabular}

$\sqrt{ } \mathrm{MSE}$, root mean square error of the statistical analysis (d.f. 28).

$\mathrm{a}, \mathrm{b}, \mathrm{c}, \mathrm{d}$ Mean values within a row with unlike superscript letters were significantly different $(P<0.05)$

${ }^{*}$ For details of diets, see Table 2.

between intake and fractional absorption of ash between diets 4 and 5 was notable, indicating that amaranth leaves contain strong inhibitors of mineral availability.

Since nutrient intakes from the different diets were not similar, it was difficult to compare the fractional $\mathrm{Ca}$ and $\mathrm{P}$ absorption directly. The method used in previous studies was therefore implemented (Larsen et al. 2000). Ca and $\mathrm{P}$ retention was related to $\mathrm{N}$ retention, thus taking into account the different growth rates of the rats.

The effect of amaranth leaves on ash digestibility was accentuated in the case of $\mathrm{Ca}$. The $\mathrm{Ca}$ intake in the rats fed diet 4 was significantly higher than those in the other dietary groups. The fractional absorption of $\mathrm{Ca}$, however, was extremely low $(0.392)$ in the rats fed diet 4, which was in contrast to the high value (0.920) found in diet 5 . The only difference between the composition of diets 4 and 5 was that the amaranth leaves were substituted by rice. The utilisation of $\mathrm{Ca}$ was obviously inhibited by components in the amaranth leaves per se. This inhibition is presumably due to a chemical sequestering of $\mathrm{Ca}$ in the digesta, i.e. outside the mucosal cells. As other leafy vegetables, amaranth leaves contain high levels of anti-nutrients, in particular oxalate. Unfortunately, the oxalate content in the amaranth leaves used in the present study was not measured. However, the content of soluble oxalate in samples of amaranth leaves collected from the same market in Bangladesh has been found to range from 38 to $50 \mathrm{~g} / \mathrm{kg} \mathrm{DM}$ (O Hels, T Larsen, LP Christensen, U Kidmose, N Hassan and SH Thilsted, unpublished results). This level is comparable with earlier published data on amaranth leaves from Hawaii (Vityakon \& Standal, 1989). Oxalate is known to form insoluble complexes with $\mathrm{Ca}$, which renders it unavailable for absorption from the digestive tract.

$\mathrm{P}$ does not receive much attention as a nutrient as it is abundantly available in a wide variety of foods (Harrison, 1984). Furthermore, the utilisation of $P$ in growing animals is closely connected to that of $\mathrm{Ca}$ and bone metabolism. $\mathrm{P}$ absorption was not compromised to the same degree as $\mathrm{Ca}$ absorption by the inclusion of amaranth leaves in the diets. However, rats fed diets 3 and 4 absorbed a significantly smaller fraction of $\mathrm{P}$ compared with those in the other dietary groups (Table 7), indicating that in diets 3 and 4 there was a larger amount of insoluble complexes with $\mathrm{P}$ in the digestive tract. It is noticeable that the urinary excretion of $\mathrm{P}$ was significantly greater in the rats fed diet 4, which contained amaranth leaves, compared with those fed diet 5, with no amaranth leaves. This can be interpreted as a reduction in the utilisation of the absorbed $\mathrm{P}$ in the rats fed diet 4 . This reduced $\mathrm{P}$ utilisation was probably related to the low level of available $\mathrm{Ca}$ and a subsequent lower deposition in bones.

The nutritional significance of the inclusion of amaranth leaves is seen very clearly in the results for the bone parameters. Femur bone mass as a proportion of body weight was inversely related to the inclusion of amaranth leaves (diets 3, 4 and 5). The highest bone mass was found in the rats fed diet 5 . The significantly higher fractional and absolute $\mathrm{Ca}$ and $\mathrm{P}$ contents in femur bones found in the rats fed diet 5 reflected that $\mathrm{Ca}$ and $\mathrm{P}$ were better retained in the animals fed this diet. In diet 2 and diet 4 , the amount of available Ca was apparently insufficient to support optimal bone growth. The availability of dietary $\mathrm{Ca}$ may alter the mineral composition of bone. $\mathrm{Ca}: \mathrm{P}$ in the femur bone was highest in the animals fed diet 5 , although the differences were not statistically different. This is in agreement with results of significantly different ratios found in our former studies (Larsen, 1993; Larsen \& Sandström, 1993b). However, in our former studies, the levels of $\mathrm{Ca}$ used within the studies were more diverse and therefore had a more marked effect on bone composition.

The present study illustrates the importance of interaction between nutrients and anti-nutrients in the diet, which may be detrimental for the nutritional status of the individual consuming the diet. In Bangladesh, the mean $\mathrm{Ca}$ intake is low, between 339 and $398 \mathrm{mg} / \mathrm{d}$ (Hels et al. 2003) and relatively constant in different seasons. In Bangladesh, small fish that are eaten with bones may be an important dietary source of $\mathrm{Ca}$ with high availability and utilisation (Larsen et al. 2000). Leafy vegetables are a common source of $\mathrm{Ca}$ in the Bangladeshi rice-based diet. However, results from the present study show that both $\mathrm{Ca}$ availability and utilisation from amaranth leaves are very low, probably due to the content of inhibitors. Increased intake of leafy vegetables is a very common 
dietary recommendation aiming to improve the micronutrient content of diets, especially of $\beta$-carotene and vitamin C. However, in formulating a balanced diet with sufficient levels of all essential nutrients, it is necessary that the contents of both nutrients and anti-nutrients are known as well as their possible interactions. The use of the rat model offers a good opportunity to test possible interactions.

\section{Acknowledgements}

Financial support from the Bilateral Programme for the Enhancement of Research Capacity in Developing Countries (ENRECA), Ministry of Foreign Affairs, Denmark is gratefully acknowledged. The authors thank Ms Kathrine Høirup, Ms Dorte Agnholt and Mr Jens Clausen, Research Centre Foulum, the Danish Institute of Agricultural Sciences for excellent technical assistance.

\section{References}

Ahmad K \& Hassan N (1983) Nutrition Survey of Rural Bangladesh, 1981-82. Dhaka, Bangladesh: Institute of Nutrition and Food Science, University of Dhaka.

Ahmed AU (1993) Patterns of Food Consumption and Nutrition in Rural Bangladesh. Washington, DC: International Food Policy Research Institute.

Ahmed F (1999) Vitamin A deficiency in Bangladesh: a review and recommendations for improvement. Pub Health Nutr 2 , $1-14$.

Ali M \& Tsou SCS (1997) Combating micronutrient deficiencies through vegetables - a neglected food frontier in Asia. Food Policy 22, 17-38.

Bowers GN \& McComb RB (1975) Measurement of total AP activity in human serum. Clin Chem 21, 1988-1995.

Eggum BO (1973) A study of certain factors influencing protein utilization in rats and pigs. Dr. Sci. dissertation. National Institute of Animal Science, report no. 406. Copenhagen, Denmark: National Institute of Animal Science.

Harrison HE (1984) Phosphorus. In Nutrition Reviews' Present Knowledge in Nutrition, 5th ed. pp. 413-421 [RE Olson, HP Broquist, CO Chichester, WJ Darby, AC Kolbye Jr and RM
Stalvey, editors]. Washington, DC: The Nutrition Foundation, Inc.

Hels O, Hassan N, Tetens I \& Thilsted SH (2003) Food consumption, energy and nutrient intake and nutritional status in rural Bangladesh: changes from 1981-82 to 1995-96. Eur J Clin Nutr 57, 586-594.

Jahan K \& Hossain M (1998) Nature and Extent of Malnutrition in Bangladesh. Bangladesh National Nutrition Survey, 1995-96. Dhaka, Bangladesh: Institute of Nutrition and Food Science, University of Dhaka.

Lakshmi B \& Vimala V (2000) Nutritive value of dehydrated green leafy vegetable powders. J Food Sci Technol 37, 465-471.

Larsen T (1993) Dephytinization of a rat diet. Consequences for mineral and trace element absorption. Biol Trace Elem Res 39, 55-71.

Larsen T \& Sandström B (1993a) Effect of dietary calcium level on mineral and trace element utilization from a rapeseed (Brassica napus, L.) diet fed to ileum-fistulated pigs. Br J Nutr 69, 211-224.

Larsen T \& Sandström B (1993b) Tissues and organs as indicators of intestinal absorption of minerals and trace elements, evaluated in rats. Biol Trace Elem Res 35, 185-199.

Larsen T, Thilsted SH, Kongsbak K \& Hansen M (2000) Whole small fish as a rich calcium source. Br J Nutr 83, 191-196.

Ministry of Health and Family Welfare (1995) Bangladesh Country Paper on Nutrition. Dhaka, Bangladesh: Bangladesh National Nutrition Council.

SAS Institute Inc. (1996) Statistical Analysis Systems, version 6.11. Cary, NC: SAS Institute Inc.

Stuffins CB (1967) The determination of phosphate and Ca in feeding stuffs. Analyst 92, 107-111.

Tetens I, Biswas SK, Glits $\varnothing$ LV, Kabir KA, Thilsted SH \& Choudhury NH (1997) Physico-chemical characteristics as indicators of starch availability from milled rice. J Cereal Sci 26, 355-361.

Tetens I, Hels O, Khan NI, Thilsted SH \& Hassan N (2003) Ricebased diets in Bangladesh: How do different age and sex groups adapt to seasonal changes in energy intakes? Am $J$ Clin Nutr, (In the Press).

Vityakon P \& Standal B (1989) Oxalate in vegetable amaranth (Amaranthus gangeticus). Forms, contents and their possible implications for human health. J Sci Food Agric 48, 469-474. 